\title{
A rare case of trisomy 18 with bilateral split-hand-foot malformation (SHFM)
}

\author{
Nydia Rena Benita Sihombing ${ }^{1}$, Asri Purwanti ${ }^{2}$, Agustini Utari ${ }^{2,3 *}$ \\ ${ }^{1}$ Doctoral Program of Medical and Health Sciences, Faculty of Medicine Diponegoro University, Semarang, \\ Indonesia \\ ${ }^{2}$ Department of Pediatrics, Faculty of Medicine Diponegoro University/ Dr. Kariadi Hospital, Semarang, \\ Indonesia \\ ${ }^{3}$ Center for Biomedical Research (CEBIOR), Faculty of Medicine Diponegoro University, Semarang, Indonesia
}

\section{Article Info}

History:

Received: 08 Nov 2018

Accepted: 09 Nov 2018

Available: 31 Dec 2018

\begin{abstract}
Background: Trisomy 18 is one of the most prevalent chromosomal aberrations in newborn, with characteristic features of internal organs such as heart and kidney abnormalities, as well as craniofacial and musculoskeletal anomalies. We presented a rare case of trisomy 18 with atypical features of split-hand-foot malformation (SHFM).

Case Presentation: A four-months-old baby was brought to hospital with dyspnea and history of multiple congenital anomalies (MCA). Abnormalities were found including brachycephaly, facial dysmorphisms, bilateral split hand and foot. Other anomalies were atrial and ventricular septal defects, umbilical hernia, and right lung atelectasis. Based on physical examination and additional workups, SHFM was suspected. Genome-wide array analysis revealed gain of entire chromosome 18 . Only few cases of SHFM trisomy 18 with split foot as the most findings have been reported.

Conclusion: This case represents bilateral SHFM as a unique limb involvement in patient with trisomy 18, a valuable finding to be taken into account in trisomy 18 phenotype. A thorough examination and routine cytogenetic analysis is vital as a first-tier diagnostic workup on patient with MCA as well as subsequent genetic counseling is granted.
\end{abstract}

Keywords: trisomy 18 syndrome; split-hand-foot malformation; ectrodactyly; genetic testing; molecular genetics

Permalink/ DOI: https://doi.org/10.14710/jbtr.v4i2.3578

\section{INTRODUCTION}

Trisomy 18 syndrome is the second most common chromosomal aneuploidy, with the prevalence of 1 in 6,000 to 8,000 newborns. The origin of an extra copy of chromosome 18 is mostly due to meiosis nondisjunction division of maternal origin. ${ }^{1}$ Some known risk factors include advanced maternal age and folic acid deficiency caused by polymorphisms on methylene tetrahydrofolate reductase $(M T H F R)$ gene. $^{2}$

\footnotetext{
* Corresponding author:

E-mail:agustiniutari@gmail.com

Tel./Fax: +62 248414296
}

Also known as Edwards syndrome, it consists of major abnormalities such as renal and heart anomalies. ${ }^{3}$ Minor anomalies including craniofacial deformities (e.g. dolichocephaly, prominent occiput) and musculoskeletal features, with classical clenched hands and rocker-bottom feet. ${ }^{4}$ Aside from the characteristic abnormalities, there have been few cases reported with ectrodactyly, mainly of feet. ${ }^{5-7} \mathrm{We}$ reported a very rare case of trisomy 18 with ectrodactyly, known as split-hand-foot malformation (SHFM) with minor characteristics. 


\section{CASE REPORTS}

A 4-months old female baby from nonconsanguineous parents was brought to Dr. Kariadi Hospital with dyspnea. She was the third child of the family from her 36-years-old mother recalled an uneventful pregnancy. She was born full term with low birth weight (2,000 grams) and multiple congenital anomalies (MCA). There was no history of miscarriages, as well as other known family member with similar condition. The other 2 siblings were healthy. Informed consent has been obtained from the parents.

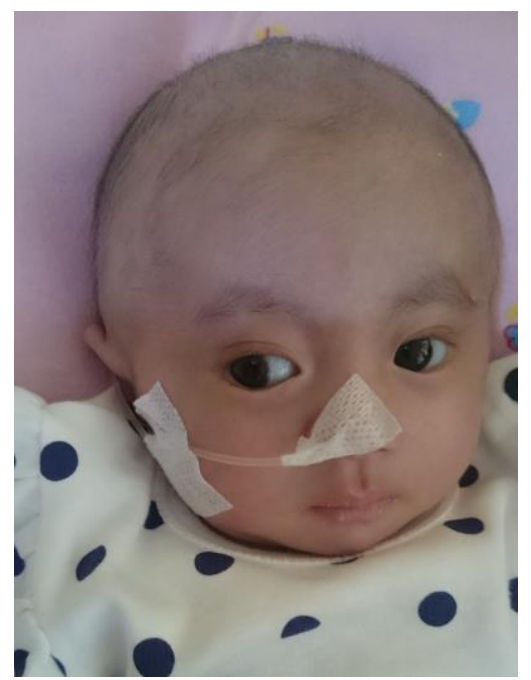

Figure 1. Facial dysmorphic features, including hypertelorism, flat nasal bridge, and micrognathia

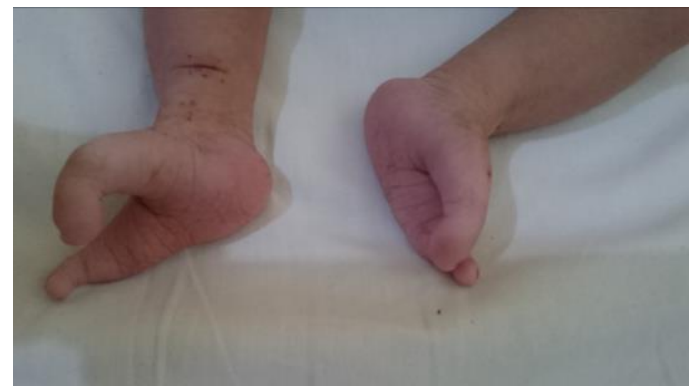

Figure 2. Presence of bilateral ectrodactyly/split foot.

In admission, there was history of delayed milestone and failure to thrive. Physical examination revealed low weight $\left(<3^{\text {rd }}\right.$ percentile $)$ and length $\left(<3^{\text {rd }}\right.$ percentile), and microcephaly $\left(34 \mathrm{~cm},<1^{\text {st }}\right.$ percentile). Craniofacial dysmorphology examination revealed brachycephaly (cephalic index: 101), hypertelorism, flat nasal bridge, low set ears, high arched palate, and micrognathia, shown in Fig. 1. Split hands and split feet were found on both extremities as shown in Fig. 2 and Fig. 3. Neurological examination showed hypotonia. Other abnormalities included an umbilical hernia and cutis marmorata, while echocardiography showed secundum atrial septal defect and ventricular septal defect with diameters 5.5 and 5.1 millimeters, respectively. Chest X-ray revealed bronchopneumonia and right lung atelectasis. Based on clinical findings, differential diagnoses were made including SHFM, acro-cardio-facial syndrome, and ectrodactyly, ectodermal dysplasia, and cleft abnormalities (EEC) syndrome. Conventional cytogenetic analysis was not carried out due to high suspicion of single gene disorders. DNA of the baby was extracted and brought for genome-wide array analysis. Array analysis revealed a gain of the entire chromosome 18, with no other genomic imbalances as shown in Fig. 4. On the later follow-up, the patient died at the age of 7 months.

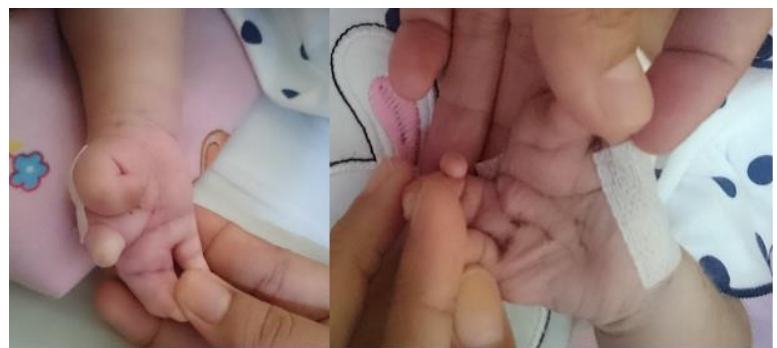

Figure 3. Presence of bilateral split hands and finger hypoplasia

\section{DISCUSSION}

The first case of trisomy 18 with ectrodactyly/SHFM was described by Butler et al (1965), in which 1 of 13 ' $E$ ' (16-18) trisomy cases had lobster claw deformities. ${ }^{8}$ An X-ray workup was done in a patient with trisomy 18 who survived for 10 hours, and feet ectrodactyly showed bilateral short hallux with complete absence of second ray and hypoplasia of the third ray on the right foot, as well as hypoplastic second and third ray on the left foot. ${ }^{5}$ The most recent trisomy 18 patient with unilateral split foot was reported as the seventh published case on Turkish patient, making our patient the eighth reported case to the best of our knowledge. ${ }^{9}$ Contrary to our case, most SHFM cases are due to single gene disorders, such as point mutations in $W N T 10 B$ and $D L X 5$, as well as missense mutations in TP63 gene. ${ }^{10,11}$ There have been six subtypes of SHFM with known candidate genes, as described in Table 1. Meanwhile, SHFM with other clinical features can be found in EEC, ectrodactylycleft palate (ECP) syndrome, Goltz syndrome, and recessive Robinow syndrome, among others. ${ }^{12}$ Thus, after consultation with clinical geneticist, our patient was indicated for array analysis to rule out the possibility of microdeletions/duplications in the chromosome, which are also prevalent for some SHFM subtypes.

In addition to SHFM, there were some clinical features in the patient which were observed in trisomy 18 patients, such as microcephaly, heart septal defects, and umbilical hernia. However, no abnormalities were found in the urogenital system, besides, both atrial and ventricular defects were found to be small in size, with approximately $50 \%$ possibility of spontaneous closure. ${ }^{13}$ Mortality in patients with trisomy 18 is mostly due to respiratory or heart failure, although recent studies found little or no association of congenital heart defects with survival rate. ${ }^{14}$ Our patient was referred at the age of 4 months, where the survival rate varies between 3 to 23 percent based on 


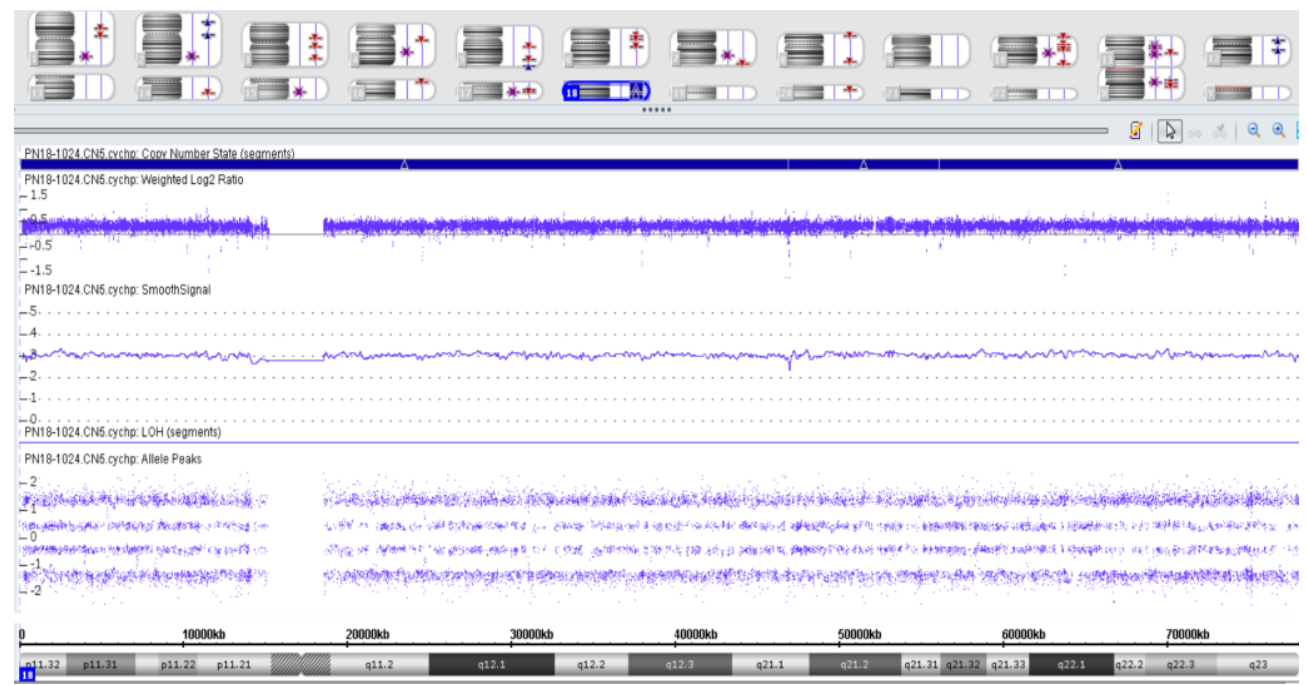

Figure 4. Genome wide array result of the patient. A gain of entire chromosome 18, denoted by the blue bar, was detected on the copy number segment, indicating trisomy 18.

studies from different countries. ${ }^{15}$ A multi-state population-based study recently revealed gestational age as the strongest predictor of mortality, with highest 1-month and 1-year survival probabilities of trisomy 18 infants born at full term (48.8 and 17.2 percent, respectively). Additionally, higher 1-year survival was found more significant in female infants compared to male counterpart (14.4 to 10.8 percent). ${ }^{16}$ These findings were evident in our case, and may serve as valuable information to be shared in the family during counseling.
The possibility of aneuploidy in our patient had been overlooked due to minor clinical features. Dysmorphic features of the hands were not immediately suggestive of trisomy 18 , due to the presence of ectrodactyly. Thus, trisomy 18 hand features such as clenched hands and overlapping fingers were not seen. This finding emphasized the need of routine cytogenetic analysis in all children with MCA, before going further with additional workups, depends on the available facilities, such as multiplex ligation-dependent probe amplification (MLPA),

Table 1. Split-hand/foot malformation subtypes (derived from Duijf et.al., 2003; Elliott et.al., 2005; Blattner et.al., 2010) $)^{12,17,18}$

\begin{tabular}{|c|c|c|c|c|}
\hline Location & Phenotype & Characteristics & Gene/locus & Inheritance \\
\hline $7 q 21.2-q 21.3$ & SHFM 1 & $\begin{array}{lcr}\text { Ectrodactyly, } & \text { some } & \text { with } \\
\text { ectodermal findings } & \text { and } \\
\text { intellectual disability } & \end{array}$ & $\begin{array}{lr}\text { Chr } & 7 \mathrm{q} 21.3 \\
\text { rearrangement, } & D L X 5 \\
\text { mutation } & \text { (with } \\
\text { hearing loss) } & \end{array}$ & $\mathrm{AD}$ \\
\hline $\mathrm{Xq} 26$ & SHFM 2 & $\begin{array}{l}\text { Split hand/foot } \\
\text { metacarpal/phalangeal } \\
\text { hypoplasia }\end{array}$ & $\begin{array}{l}\text { Chr Xq26.3 between } \\
\text { markers DXS1114 - } \\
\text { DXS1192 }\end{array}$ & X-linked \\
\hline 10q24 & SHFM 3 & $\begin{array}{l}\text { Micrognathia, high arched } \\
\text { palate, renal hypoplasia, ear } \\
\text { abnormalities }\end{array}$ & Duplication of 10q24 & $\mathrm{AD}$ \\
\hline $3 q 28$ & SHFM 4 & Variable phenotypes & $\begin{array}{l}\text { Missense mutation of } \\
p 63 \text { gene }(724 \mathrm{~A}>\mathrm{G}, \\
928 \mathrm{~T}>\mathrm{C})\end{array}$ & $\mathrm{AD}$ \\
\hline $2 \mathrm{q} 31$ & SHFM 5 & $\begin{array}{l}\text { Split hand/foot, some with } \\
\text { craniofacial findings and } \\
\text { orofacial clefting }\end{array}$ & $\begin{array}{l}\text { Rearrangement of chr } \\
2 \mathrm{q} 31 \text { involving } \\
H O X D 9 \text { and EVX2 } \\
\text { gene }\end{array}$ & $\mathrm{AD}$ \\
\hline $12 q 13.12$ & SHFM 6 & $\begin{array}{l}\text { Variable phenotypes, history of } \\
\text { consanguinity }(+)\end{array}$ & $\begin{array}{l}\text { Homozygous } \\
\text { mutation in } W N T 10 B \\
\text { gene }\end{array}$ & AR \\
\hline
\end{tabular}

Note: $\mathrm{AD}=$ autosomal dominant, $\mathrm{AR}=$ autosomal recessive, $\mathrm{SHFM}=$ split-hand-foot malformation 
genome wide array analysis, and targeted/whole gene sequencing.

As for the genetic counseling, the risk of recurrence of classic trisomy is less than $1 \%$, since the condition is due to meiotic nondisjunction. Counseling session should be done with caution, especially for preparation prior to next pregnancy due to increased maternal age (i.e. more than 35 years old) when the family decide to have more children.

\section{CONCLUSION}

We present a rare case of trisomy 18 with bilateral SHFM. In examining children with MCA and limb anomalies, trisomy 18 needs to be considered as a differential diagnosis, and routine cytogenetic analysis is crucial to be done as the first-tier workup. Further studies by next-generation sequencing may be useful to elucidate new genes responsible for SHFM in trisomy 18.

\section{ACKNOWLEDGEMENTS}

We would like to thank Nicole de Leeuw, $\mathrm{PhD}$, Hans van Bokhoven, $\mathrm{PhD}$ and Ineke van der Burgt, $\mathrm{MD}, \mathrm{PhD}$ from Radboud university medical center, Nijmegen, The Netherlands for their cytogenetic, molecular and clinical expertise. This study was supported by grant of Program Pendidikan Magister menuju Doktor untuk Sarjana Unggul (PMDSU) from Indonesia Ministry of Research, Technology and Higher Education (grant no. 2064.22/D3/PG/2017).

\section{REFERENCES}

1. Houlihan OA, O'Donoghue K. The natural history of pregnancies with a diagnosis of Trisomy 18 or Trisomy 13; a retrospective case series. BMC Pregnancy Childbirth. 2013;13(1):209.

2. Guo Q, Wang H, Yang K, Zhang B, Li T, Liao S. [Association of MTHFR and MTRR genes polymorphisms with non-disjunctions of chromosomes 18 and 21]. Chinese J Med Genet. 2015;32(3):395-9.

3. Cereda A, Carey JC. The trisomy 18 syndrome. Orphanet J Rare Dis. 2012;7:81.

4. Roberts W, Zurada A, Zielinska AZ, Gielecki J, Loukas M. Anatomy of Trisomy 18. Clin Anat. 2016;29:628-32.

5. Castle D, Bernstein R. Trisomy 18 syndrome with cleft foot. J Med Genet. 1987;568-70.

6. Rogers C. Trisomy 18 With Unilateral Atypical Ectrodactyly. Am J Med Genet. 1994;49:125-6.

7. Becerra M, Moya F, Lacassie Y, Stopa A, Craver R. Clinico-pathological conference: A preterm infant with multiple congenital anomalies. Am J Med Genet. 1992;44(4):503-7.

8. Butler LJ, Snodgrass GJAI, France NE, Sinclair L, Russell A. E (16-18) trisomy syndrome: analysis of 13 cases. Arch Dis Child. 1965;40:600-11.

9. Kislal FM, Altuntas N, Ozdemir O, Ceylaner S, Kislal MH, Andiran N. Unilateral Ectrodactyly in a Newborn with Trisomy 18 Syndrome: An Unusual Association. J Coll Physicians Surg Pak. 2015;25(8):619-20.
10. Sowińska-Seidler A, Socha M, Jamsheer A. Splithand/foot malformation - molecular cause and implications in genetic counseling. J Appl Genet. 2014;55(1):105-15.

11. Yang X, Lin X, Zhu Y, Luo J, Lin G. Genetic analysis of a congenital split-hand/split-foot malformation 4 pedigree. Mol Med Rep. 2018;17(6):7553-8.

12. Duijf PHG, Bokhoven $\mathrm{H}$ Van, Brunner HG. Pathogenesis of split-hand / split-foot malformation. Hum Mol Genet. 2003;12(1):5160.

13. McMahon CJ, Feltes TF, Fraley JK, Bricker JT, Grifka RG, Tortoriello TA, et al. Natural history of growth of secundum atrial septal defects and implications for transcatheter closure. Heart. 2002;87(3):256-9.

14. Rosa RFM, Rosa RCM, Lorenzen MB, Zen PRG, Oliveira CAV de, Graziadio C, et al. Limb abnormalities on trisomy 18: evidence for early diagnosis. J Pediatr (Rio J).2012;88(5):401-5.

15. Rosa RFM, Rosa RCM, Zen PRG, Graziadio C, Paskulin GA. Trisomy 18 : review of the clinical, etiologic, prognostic , and ethical aspects. Rev Paul Pediatr. 2013;31(1):111-20.

16. Meyer RE, Liu G, Gilboa SM, Ethen MK, Aylsworth AS, Powell CM, et al. Survival of children with trisomy 13 and trisomy 18: A multistate population-based study. Am J Med Genet Part A. 2016;170(4):825-37.

17. Elliott A, Evans J, Chudley A. Split Hand Foot Malformation (SHFM). Clin Genet. 2005;68(6):501-5.

18. Blattner A, Huber AR, Röthlisberger B. Homozygous nonsense mutation in WNT10B and sporadic split-hand/foot malformation (SHFM) with autosomal recessive inheritance. Am J Med Genet Part A. 2010;152A(8):2053-6. 